\title{
Oribatid mites (Acari: Oribatida) from roofs of houses in Sogn og Fjordane (Norway)
}

\author{
RADOMIR GRACZYK ${ }^{1}$ and STANISŁAW SENICZAK ${ }^{2}$ \\ ${ }^{1}$ Department of Ecology, University of Technology and Life Sciences, Kordeckiego 20, \\ 85-225 Bydgoszcz, Poland \\ ${ }^{2}$ Department of Zoology, Kazimierz Wielki University, Ossolińskich 12, 85-092 Bydgoszcz, Poland \\ Corresponding author: Radomir Graczyk, graczyk@utp.edu.pl
}

(Received on 13 January 2012; Accepted on 21 May 2013)

\begin{abstract}
Oribatid mite communities in moss covering the roofs of buildings in towns of Bolstad, Luster, and Sørheim (in Sogn og Fjordane, Norway) were investigated. These mites were rather numerous and rich in species, which was caused mainly by the natural roofing material (rock slates) and the temperate and rather stable maritime climate. In these communities the most abundant were Tectocepheus velatus, Dissorhina ornata, Oppiella uliginosa, Quadroppia quadricarinata, and Oribatula exilis, which are typical soil species. Adults usually dominated in the mite communities, except for Bolstad, where the juveniles were slightly more abundant than the adults. Phauloppia lucorum and Trhypochthonius tectorum were the only species of the group of typical inhabitants of roofs of buildings, but were not numerous in Sogn og Fjordane. In continental climate these species are often abundant on roofs of buildings.
\end{abstract}

Keywords: urban habitats, roofs of buildings, rock slates, moss, Oribatida, juveniles

\section{INTRODUCTION}

For hundreds of years there is a tradition in Norway to cover buildings with rock slates, which are cheap, long-lasting, heavy, and therefore resistant to strong winds. With time, these slates are usually overgrown by a thick layer of moss, forming ,green roofs", which effectively protect the houses against freezing. They also enlarge the green area of landscape and its species diversity, and create interesting elements for tourists. In contrast, the modern materials are more expansive, of short duration, rather light, can be easily damaged by strong wind, and are alien to the landscape.

One of the most interesting places to visit in Norway is the county Sogn og Fjordane, which occupies an area of $18623 \mathrm{~km}^{2}$ along the longest Norwegian fjord Sognefjord (204 km long). This is a post-glacial area, with rather high mountains sloping sharply nearly to the fjord, and with many waterfalls. The climate is mari- 
time, with annual precipitation of about $2000 \mathrm{~mm}$ and prevailing west winds. Summers are relatively cold and wet there, with average temperature about $17^{\circ} \mathrm{C}$, whereas winters are mild and also wet.

These climatic conditions are good for moss, which covers the slates of roofs of buildings, and also for soil animals that inhabit moss, including the oribatid mites. The rock slates are covered by thick layer of moss, which resembles the upper soil horizon, with abundant mites that decompose organic matter and release mineral elements necessary for moss (KRZYSZTOFIAK et al. 2010). Mosses covering the slates are pioneer plants, able to grow on nutrient-poor rocks and soil.

The aim of this study was to investigate the oribatid mite fauna in the specific, nutrient-poor rock habitat, i.e. moss on rock slates covering roofs of buildings in 3 towns of Sogn og Fjordane. We investigated the density and species composition of these mites, and also the age structure of species, which are rarely included in ecological papers.

\section{MATERIAL AND METHODS}

The building roofs with rock slates and moss were chosen for this study in 3 towns of Sogn og Fjordane in Norway (Fig. 1): Bolstad (61 $\left.{ }^{\circ} 29.43^{\prime} \mathrm{N}, 7^{\circ} 35.45^{\prime} \mathrm{E}\right)$, Lus$\operatorname{ter}\left(61^{\circ} 26.33^{\prime} \mathrm{N}, 7^{\circ} 27.21^{\prime} \mathrm{E}\right)$, and Sørheim $\left(61^{\circ} 25.21^{\prime} \mathrm{N}, 7^{\circ} 29.30^{\prime} \mathrm{E}\right)$. All the roofs were situated at 30-65 m a.s.l., had a south exposure. Moss covered $100 \%$ of roof areas, with dominant Polytrichum sp., while Hypnum sp. was less abundant.

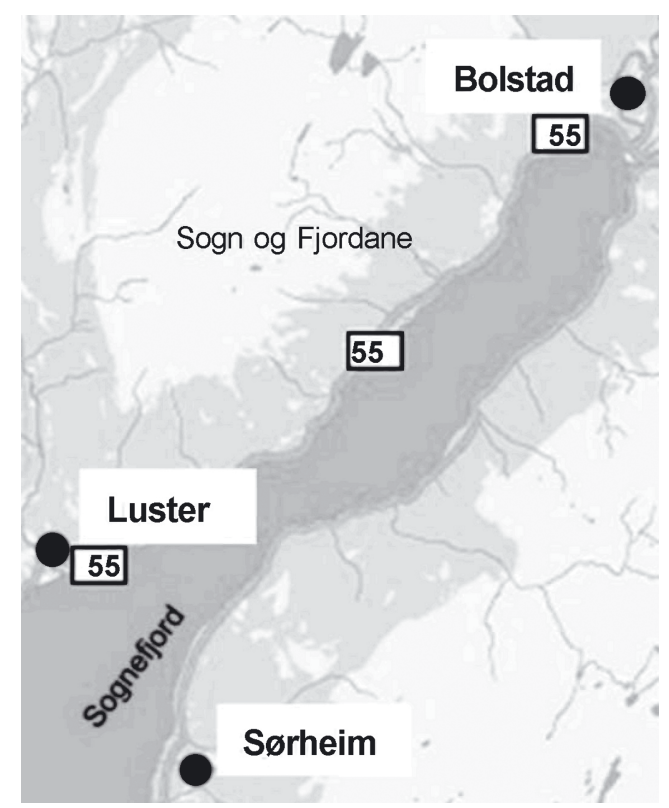

Fig 1. Location of the investigated plots in Sogn og Fjordane (http://maps.google.pl, modified) 
Samples of moss (of $500 \mathrm{~cm}^{3}$ each) were taken on 25-26 August 2005, in 20 replicates. Mites were extracted from them using high-gradient Tullgren funnels, and conserved in $70 \%$ alcohol. Oribatid mites were determined to species or genus, including the juveniles. In total, 17385 oribatid mites were investigated.

We characterized the oribatid species with the abundance, dominance, and constancy indices, while the mite communities were compared with the Shannon $H^{\prime}$ index (ODum 1971). Species structure of oribatid communities between investigated habitats was compared using Bray-Curtis similarity (BRAY \& CURTIS 1957). The similarity matrices were subjected to cluster analysis, employing the unweighted pairgroup method with arithmetic averaging (UPGMA).

Basic descriptive statistics for species were also counted. Compliance with normal distribution was tested with the Kolmogorov-Smirnov test, while the homogeneity of variance, with the Levene test. The assumptions of variance analysis have not been met, so nonparametric tests were used: Kruskal-Wallis one-way ANOVA and the $U$ Mann-Whitney test, and significance of differences between averages was assessed by the Kruskal-Wallis test (STANISz 2006a, b). The level of significance for all statistical tests was accepted at $\alpha=0.05$. The obtained data were statistically analysed using MS Excel 2007, Statistica 6.0, and MVSP 3.2 software (Kovach Computing Services 2010). Names of oribatid species follow WeIGmann (2006).

\section{RESULTS}

The density of oribatid mites in moss on the roofs of buildings was the highest in Bolstad and the lowest in Luster (Table 1). The richest in species were oribatid mite communities in Sørheim, while the poorest in species were those in Luster. Consequently, the highest Shannon $H^{\prime}$ index of these mites was in Sørheim, and the lowest in Bolstad. Generally, the oribatid mites were rich in species ( 29 species in total), but only 12 species were present in all towns.

Table 1. Characteristics of oribatid mite communities in moss from roofs of selected houses in Sogn og Fjordane: mean density (individuals per sample, i.e. $500 \mathrm{~cm}^{3}, n=20$ ), number of species, and Shannon index of diversity $\left(H^{\prime}\right)$

\begin{tabular}{lccr}
\hline \multicolumn{1}{c}{ Characters } & Sørheim & Bolstad & Luster \\
\hline Mean density of Oribatida & 297.7 & 437.5 & 134.0 \\
Mean density of juveniles & 19.2 & 259.3 & 4.0 \\
Number of species & 25 & 23 & 15 \\
Shannon index $H^{\prime}$ & 1.94 & 0.69 & 1.32 \\
\hline
\end{tabular}




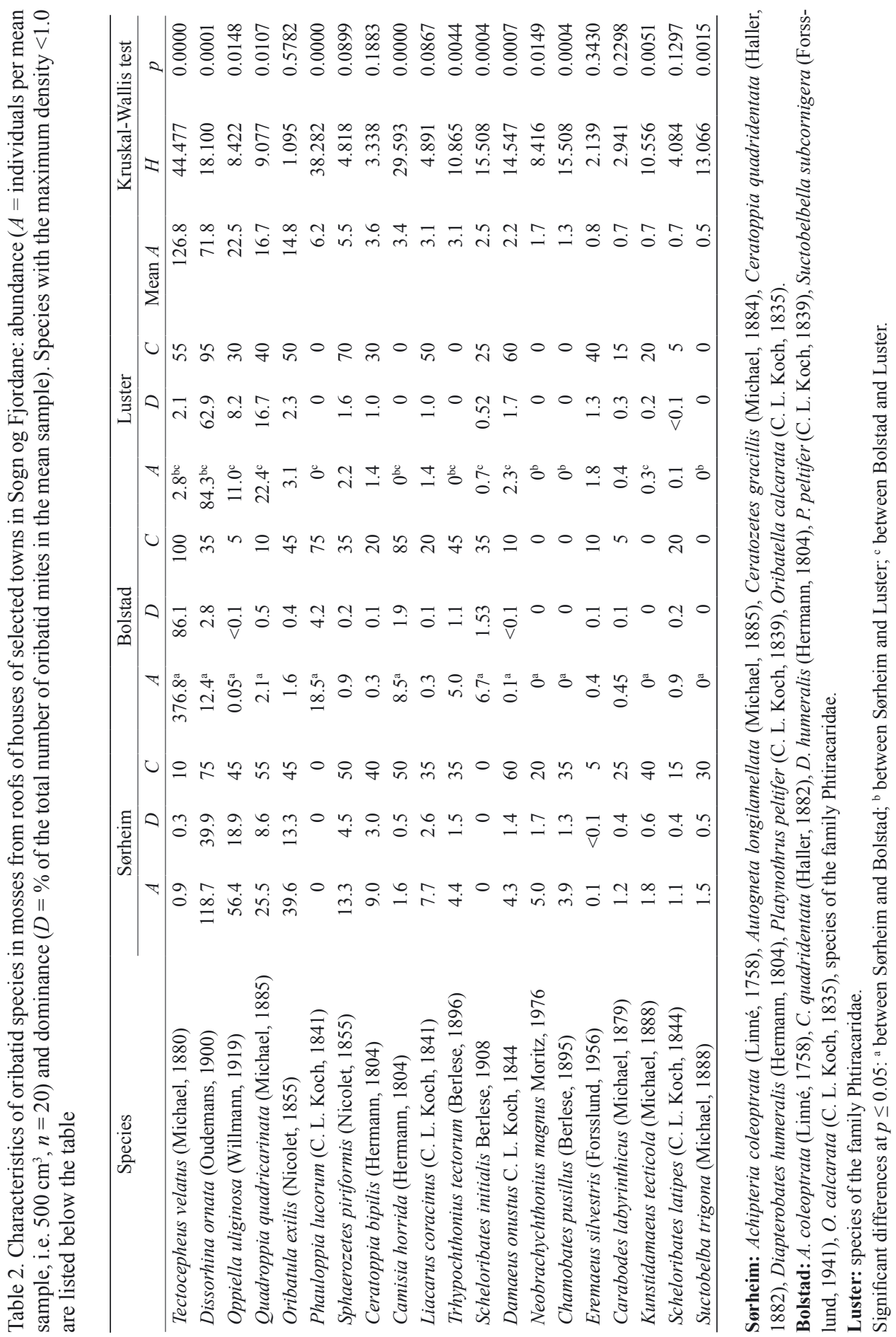


Among the oribatid mites the most abundant were Tectocepheus velatus (Michael, 1880), Dissorhina ornata (Oudemans, 1900), Oppiella uliginosa (Willmann, 1919), and Quadroppia quadricarinata (Michael, 1885), but their densities in the towns were significantly differed (Table 2). For example, Tectocepheus velatus highly dominated in Bolstad, but was not abundant in Sørheim and Luster. In the latter towns, Dissorhina ornata, Oppiella uliginosa, and Quadroppia quadricarinata dominated, but those species were not abundant in Bolstad. Thus, similarity of oribatid mites was the highest between Sørheim and Luster (Fig. 2).

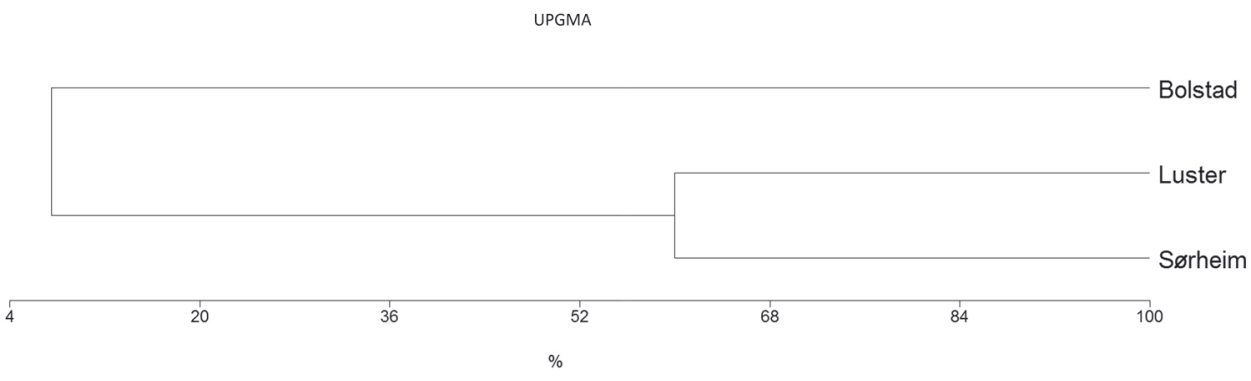

Fig 2. Cluster analysis of Oribatida groups of the investigated habitats (UPGMA method by using the percentage similarity)

Table 3. Age structure of selected species of oribatid mites, which are usually rich in juveniles (mean density of individuals in $500 \mathrm{~cm}^{3}$ ), in moss from roofs of houses in 3 towns of Sogn og Fjordane (Norway): juv = juveniles; ad $=$ adult; tot $=$ total

\begin{tabular}{llrrr}
\hline Species & Town & juv & ad & tot \\
\hline Camisia horrida & Bolstad & 6.5 & 2.0 & 8.5 \\
& Sørheim & 1.4 & 0.2 & 1.6 \\
Ceratoppia bipilis & Sørheim & 6.3 & 2.7 & 9.0 \\
Damaeus onustus & Luster & 0.8 & 0.6 & 1.4 \\
Kunstidamaeus tecticola & Sørheim & 3.0 & 1.3 & 4.3 \\
Phauloppia lucorum & Luster & 1.3 & 1.0 & 2.3 \\
Oribatula exilis & Sørheim & 0.2 & 1.6 & 1.8 \\
& Bolstad & 15.1 & 3.4 & 18.5 \\
& Sørheim & 9.8 & 29.8 & 39.6 \\
Sphaerozetes piriformis & Bolstad & 0.4 & 1.2 & 1.6 \\
Tectocepheus velatus & Luster & 0.7 & 2.4 & 3.1 \\
& Sørheim & 5.1 & 8.2 & 13.3 \\
Trhypochthonius tectorum & Luster & 1.3 & 0.9 & 2.2 \\
& Bolstad & 232.8 & 144.0 & 376.8 \\
& Luster & 1.3 & 1.5 & 2.8 \\
\hline
\end{tabular}


Age structure of oribatid mites depended on species. Tectocepheus velatus in Bolstad was rich in juveniles, which constituted $61.8 \%$ of its population, while in other towns the density of this species was smaller, with a lower participation of juveniles (Table 3). The juveniles also dominated in Camisia horrida (Hermann, 1804), Phauloppia lucorum (C. L. Koch, 1841), and Trhypochthonius tectorum (Berlese, 1896). In Ceratoppia quadridentata (Haller, 1882), the juveniles dominated only in Bolstad, while in C. bipilis (Hermann, 1804) and Damaeus onustus C. L. Koch, 1844, they dominated in Sørheim and Luster. In other species, the adults were more abundant than the juveniles.

\section{DISCUSSION}

Moss microhabitats on rock slates on roofs of buildings in the 3 selected towns at Sogn og Fjordane create favourable habitats for oribatid mites, so the mite communities were abundant and rich in species, compared to typical roofs covered with tar paper and asbestos cement. The density of oribatid mites was the lowest in Luster, comparable with that on roofs covered with tar paper and asbestos cement in suburbs of Bydgoszcz (Poland). However, the number of species of oribatid mites in Luster was about 2-fold higher than in Bydgoszcz (GRACZYK et al. 2011).

In oribatid mite communities in Sogn og Fjordane, the most abundant were Tectocepheus velatus, Dissorhina ornata, Oppiella uliginosa, and Quadroppia quadricarinata, which belong to typical soil species and require rather high air humidity (RAJSKI 1968). This is partly confirmed by an observation of BonNET et al. (1975), who found Tectocepheus velatus and Oribatula exilis (Nicolet, 1855) abundant in moss and lichens covering the rocks, but the former species preferred the bottom of these rocks, while the latter species the top of rocks. GJELSTRUP (1979) found T. velatus to be the most abundant in lower parts of beech trunks, near the root collar with Mnium hornum, while Oribatula exilis occurred in Hypnum sp. covering the higher part of the trunks. On birch trunks, the former mite species occurred in the Dicranum zone, covering the lower part of the trunks, while Carabodes labyrinthicus (Michael, 1879) dominated in the lichen zone above the Dicranum zone. In saxicolous lichens covering the northern cliff of Bornholm, sloping to the Baltic Sea, Phauloppia coineaui Travé, 1961 was most common, while Ph. lucorum (C. L. Koch. 1841) and Carabodes labyrinthicus were less abundant (GJElstrup \& Søchting 1979). Juveniles of Phauloppia were abundant there.

By contrast, in moss covering the typical roofs in suburbs of Bydgoszcz (tar paper and asbestos cement) the most abundant were xerophiles, like Trichoribates trimaculatus, Trhypochthonius tectorum, Scutovertex Michael, 1879, and Phauloppia lucorum. Those species are considered typical of moss patches that cover solid substrates, including rock and roofs of buildings (TRAVÉ 1963; SMRŽ 1992a; GRACZYK et al. 2011). Trichoribates trimaculatus and Phauloppia lucorum were the most abundant in lichens covering the tree trunks (ANDRÉ 1984, 1985), where the former species preferred foliose lichens.

The dominance structure of xerophilous species probably depends on geographic region. In moss covering typical roofs of buildings in central Bohemia (Czech 
Republic), investigated by SMRŽ (1992a), the most abundant was Scutovertex minutus (C. L. Koch, 1835) and next most abundant were Trichoribates trimaculatus and Phauloppia lucorum. Out of these species, in Sogn og Fjordane only Phauloppia lucorum and Trhypochthonius tectorum occurred, but rather in small numbers, which was probably caused by higher air moisture. The former species was also observed on roofs of buildings by WILLMANN (1931). Generally, the oribatid mites inhabiting roofs of buildings are specific to this habitat type, and many species can be transferred from one roof to another by birds, which carry them in feathers (KRIVOLUTSKY \& LEBEDEVA 2002).

In oribatid mite communities in Sogn og Fjordane, the adults usually dominated, except for Bolstad, where juveniles were slightly more abundant than adults, and this age structure is typical of soil mites. In contrast, the oribatid mites inhabiting the typical roofs were richer in juveniles, which often dominated in oribatid mite communities (SMRŽ 1992a; GRACZYK et al. 2011). The numerous juvenile mites play an important role in decomposition of organic matter and releasing the nutrients for moss, because they are more active than the adults (BERTHET 1963), and have a more active gut microflora, which digests even decay-proof substances, such as cellulose, lignin, and chitin (Stefaniak \& Seniczak 1976).

According to SMRŽ (1992b), some species of oribatid mites inhabiting the roofs of buildings are well adapted to arid climate by the strongly sclerotized integument of adults and the plicate and rather thick cuticle of juveniles, like in Scutovertex. In juveniles of Trichoribates trimaculatus and Phauloppia lucorum, secretion of opisthonotal glands is important. It covers the body and lowers the water loss by mites. Scutovertex minutus tolerates both arid climate and flooding for several weeks (SMRŽ 1994), and these climatic conditions may occur on roofs of buildings.

SMRŽ (1992a) investigated in detail the annual dynamics of density of S. minutus and Trichoribates trimaculatus. The former species was the most abundant in July, both as juveniles and adults, but in the latter species the adults dominated in July, whereas the juveniles in October. Presence of abundant juvenile mites of these species on roofs of buildings indicates that they live and develop there. These species differ also in rate of locomotion, resistance to drought, and food selection (SMRŽ 2006), which is important on roofs of buildings. Trichoribates trimaculatus is running quickly, both as juvenile and adult, while Scutovertex minutus is a slow-moving mite. The former species can swim due to hydrophobic body, while the latter species is hydrophilic and sinks to the bottom. Both species are panphytophagous (LuXTON 1972), but Trichoribates trimaculatus prefers algae and omits the fungi, while Scutovertex minutus has a broader diet, including fungi (SMRž 2006).

The presented results illustrate some characters of populations of oribatid mites, which enrich our knowledge on ecology of some species of oribatid mites. The green roofs from Norway are also promoted by new Polish and European building industry, in order to enlarge green areas and improve the landscape value of new buildings. Therefore, when these green roofs in Poland will develop their own flora and fauna, the results on oribatid mites can be compared with our results from Norway. 


\section{CONCLUSIONS}

1. Oribatid mites on roofs of buildings in Sogn og Fjordane were abundant and rich in species, which was caused mainly by the natural substrate (rock slates) and the temperate, maritime climate.

2. In the oribatid mite communities, the most abundant were Tectocepheus velatus, Dissorhina ornata, Oppiella uliginosa, and Quadroppia quadricarinata, which are typical soil species.

3. Adult mites usually dominated in the oribatid communities, except for Bolstad where the juveniles were slightly more abundant than the adults.

4. Phauloppia lucorum and Trhypochthonius tectorum were the only species representing the group of typical inhabitants of roofs of buildings in continental climate, but were not numerous in Sogn og Fjordane.

\section{REFERENCES}

ANDRÉ H. M. 1984. Notes on the ecology of corticolous epiphyte dwellers. 3.Oribatida. Acarologia 25: 385-395.

ANDRÉ H. M. 1985. Association between corticolous microarthropod communities and epiphytic cover on bark. Holarctic Ecology 8: 113-119.

Berthet P. 1963. Mesure de la consummation d.oxygene des Oribates (Acariens) de la litiere des forêts [Measurement of the consumption of oxygen by Oribatida (Acari) of the forest litter]. In: Soil organisms (Doeksen J., Drift J. V. D., Eds.), pp. 18-31, North Holland Publ., Amsterdam (in French).

Bonnet L., Cassagnau P., Travé J. 1975. L'Ecologie des Arthropodes muscicoles la lumiére de 1'Analyse des Correspondances: Collemboles et Oribates du Sidobre (Tarn, France) [The Ecology of Arthropodes muscicoles in the light of correspondence analysis: Colembola and Oribatida of Sidobre (Tarn, France)]. Oecologia (Berl.) 21: 359-393 (in French).

BRAY J. R., CuRTIS J. T. 1957. An ordination of the upland forest communities of Southern Wisconsin. Ecol. Monogr. 27: 325-349.

GJELSTRUP P. 1979. Epiphytic cryptostigmatic mites on some beech- and birch-trees in Denmark. Pedobiologia 19: 1-8.

Gjelstrup P., Søchting U. 1979. Cryptostigmatic mites (Acarina) associated with Ramalina siliquosa (Lichenes) on Bornholm in the Baltic. Pedobiologia 19: 237-245.

Graczyk R., Seniczak S., Bukowski G., Chachaj B. 2011. Preliminary studies on the mite fauna (Acari) from mosses covering the roofs of buildings in Bydgoszcz (Poland). In: Urban Fauna. Studies of animal biology, ecology and conservation in European cities (INDYKIEWICZ P., JERZAK L., Bóhner J., KaVanagh B., Eds.), pp. 83-90, UTP Bydgoszcz.

Krivolutsky D. A, Lebedeva N. V. 2002. The oribatid mites and other microarthropods in the bird feathers. In: Studies on soil fauna in Central Europa (TAjovsky K., Balik V., Pizl V., Eds.), pp. 101-104, Institute of Soil Biology, Academy of Sciences, Ceske Budejovice.

Krzysztofiak L., Krzysztofiak A., Romański M. 2010. Świat śluzowców, grzybów i mszaków Wigierskiego parku narodowego [The world of slime molds, fungi and bryophytes of the Wigierski National Park]. Stowarzyszenie „Człowiek i Przyroda”, Suwałki (in Polish).

Luxton M. 1972. Studies on the oribatid mites of a Danish beech wood soil. I. Nutritional biology. Pedobiologia 12: 434-463. 
RAJSKI A. 1968. Autecological-zoogeographical analysis of moss mites (Acari, Oribatei) on the basis of fauna in the Poznan Environs. Part II. Fragm. Faun. 14: 277-405.

Odum E. P. 1971. Fundaments of ecology. W. B. Saunders Co., Georgia.

SMRŽ J. 1992a. Some adaptive features in the microanatomy of moss-dwelling oribatid mites (Acari, Oribatida) with respect to their ontogenic development. Pedobiologia 36: 306-320.

SMRŽ J. 1992b. The ecology of the microarthropod community inhabiting the moss cover of roofs. Pedobiologia 36: 331-340.

SMRŽ J. 1994. Survival of Scutovertex minutus (Koch) (Acari, Oribatida) under different humidity conditions. Pedobiologia 38: 448-454.

SMRŽ J. 2006. Microhabitat selection in the simple oribatid community dwelling in epilithic moss cover (Acari: Oribatida). Naturwissenschaften 93: 570-576.

Stanisz A. 2006a. Przystępny kurs statystyki z zastosowaniem Statistica PL na przykładach z medycyny 1. Statystyki podstawowe [Readable course in statistics using Statistica PL, with examples from medicine 1. Basic Statistics]. StatSoft Polska, Kraków (in Polish).

Stanisz A. 2006b. Przystępny kurs statystyki z zastosowaniem Statistica PL na przykładach z medycyny 2. Modele liniowe i nieliniowe [Readable course in statistics using Statistica PL, with examples from medicine 2. Linear and nonlinear models]. StatSoft Polska, Kraków (in Polish).

Stefaniak O., Seniczak S. 1976. The microflora of the alimentary canal of Achipteria coleoptrata (Acarina, Oribatei). Pedobiologia 16: 185-194.

TRAVÉ J. 1963. Ecologie et biologie des Oribates (Acariens) saxicoles et arboricoles. Vie et Milieu, Suppl. 14: 1-267.

Weigmann G. 2006. Hornmilben (Oribatida) [Oribatid mites (Oribatida)]. In: Die Tierwelt Deutschland und der angrenzenden Meeresteile 76. Teil (DAнL F., Ed.), p. 1-520, Goecke \& Evers, Keltern (in German).

Willmann C. 1931. Moosmilben oder Oribatiden (Cryptostigmata) [Oribatid mites or Oribatida (Cryptostigmata)]. In: Die Tierwelt Deutschlands. Bd. 22 (DAHL F., Ed.), pp. 79-200, Fischer Jena (in German). 